DOI: 10.2478/linpo-2013-0015

\title{
PRENOMINAL PARTICIPIAL PHRASES IN MARATHI, THE NOUN PHRASE ACCESSIBILITY HIERARCHY, AND PICTURE NOUNS ${ }^{1}$
}

\author{
PETER EDWIN HOOK, PRASHANT PARDESHI
}

\begin{abstract}
Peter Edwin Hook, Prashant Pardeshi. Prenominal Participial Phrases in Marathi, the Noun Phrase Accessibility Hierarchy, and Picture Nouns. The Poznan Society for the Advancement of the Arts and Sciences. PL ISSN 0079-4740, ISBN 978-83-7654-274-4, pp. 77-89.

An introduction to Keenan and Comrie's NPAH (noun phrase accessibility hierarchy) is followed by data showing to what extent Marathi's PPPs (prenominal participial phrases) do and do not conform to it. The range of constructional variety inside a PPP is shown to be related to the tightness or looseness of the relation of the predicate inside the PPP to the nulled element. Examples are presented of the puzzling absence of Agent and Experiencer noun phrases inside PPPs. The paper ends with examples and discussion of the mismatch or transfer of PPP modifiers away from the NP denoting the 'imagee' or entity depicted in an image to the NP denoting the image itself.
\end{abstract}

KEY WORDS: Marathi, prenominal participial phrase, noun-phrase accessibility hierarchy, relativization, picture nouns, mismatches

Peter Edwin Hook, Universities of Michigan and Virginia, peter.e.hook@gmail.com; Prashant Pardeshi, National Institute for Japanese Language \& Linguistics, prashant@ninjal.ac.jp

\section{INTRODUCTION}

In $1977^{2}$ Edward Keenan and Bernard Comrie introduced the notion of the "noun phrase accessibility hierarchy" (hereafter NPAH) as a way of ordering disparate cross-linguistic data on the scope of relativization constructions. The NPAH is represented as a series of positions along a scale of relativizability:

$$
\text { Subject }>\text { Direct Obj }>\text { Indir Obj }>\text { Oblique Obj }>\text { Possessor }>\text { Obj of Comparison }
$$

The NPAH is an implicational hierarchy. Any position on it that is relativizable in a given language implies relativizability of all the positions to its left. For each position there is at least one language for which positions to its right are not relativizable. The consequence of this is that the NPAH partitions the world's languages into seven types.

1 The research reported on here was inspired by a series of workshops on PPPs at Stanford organized by Y. Matsumoto and by K.V. SubBarao's discussion of them (2012: chapter 8). Our paper has benefitted from intensive discussion of its contents with E. Annamalai.

2 In a later paper (1979) COMRIE and KEENAN presented data from a wide variety of languages to justify the identification of each of the six positions on the NPAH. 
At first the Marathi data does not seem to contradict or counter-exemplify the NPAH. As we shall see, however, the devil is in the details!

The rest of the paper is divided into the following sections:

1. Marathi's prenominal participial phrases and the NPAH

2. Violations of the NPAH

3. Two classes of positions on the NPAH

4. The missing Agent mystery [as yet unsolved]

5. PPPs and picture nouns

\section{MARATHI'S PRENOMINAL PARTICIPIAL PHRASES AND THE NPAH}

Among Marathi's prenominal participial phrases ${ }^{3}$ [PPPs] are two types that are based on the past and the present [= non-past] participles, V-lel- and V-ṇār-:

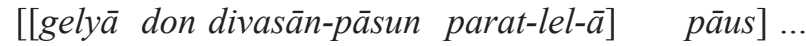
past two days-since return-PstPart-Msg rain(Msg)

'[The rain [(that) returned two days ago $]]$...'

(maharashtratimes.indiatmes.com)

[[dar-varși 15 ogast-nantar parat-ṇār-ā $] \quad$ pāus $] \ldots$ (intransitive subject) every-year 15 August-after return-PresPart-Msg rain(Msg)

'[The rain [(that) returns every year after 15 August]] ...' (prahaar.in)

With the [cross-linguistically common] exception of the very last segment (namely, the 'Object of comparison') the PPP in -lel- visits every stop on Keenan and Comrie's NPAH:

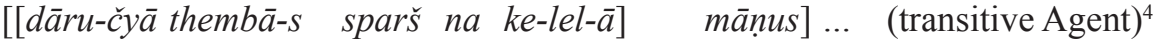

$$
\begin{aligned}
& \text { '[A man [(who) hasn't touched a drop of alcohol]] ...' (www.misalpav.com) }
\end{aligned}
$$

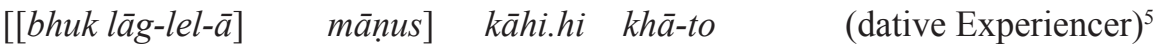

$$
\begin{aligned}
& \text { hunger stick-PstPart-Msgman(Msg) anything eat-M3sgPres } \\
& \text { '[A man [(who) is hungry]] eats anything.' (goo.gl/Gk9kAK) }
\end{aligned}
$$

3 For a comprehensive overview of all of Marathi's PPPs, see Hook \& PARDESHI [in press]. They are mentioned in PAndharipande (1997: 89-91) and Dhongde \& Wali (2009: 222-223). Hook \& Koul (MS) is a description of PPPs in Hindi-Urdu and Kashmiri. Kannada PPPs are briefly treated in (SRIDHAR 1990: 49-51) and Tamil's, at great length in a monograph dedicated to them (ANNAMALAI 1997). MASICA (1991: 408-410) compares PPPs in Indo-Aryan. Subbarao (2012: 263-335) is a comparison covering all of South Asia.

4 We have introduced sub-distinctions to facilitate an understanding of the Marathi data. The KeenanComrie NPAH does not distinguish transitive Agents from intransitive subjects.

5 From a syntactic point of view Experiencers in constructions like that in (5) are a (sub-type of) Agent: They antecede reflexive possessives (a) and they control gerunds (b):

(a) ti-lā svatahā-tse ghar have hote her-Dat self-Gen house necessary was

'She wanted a house of her own.' [Lit: 'To her (an) own house was necessary.']

(b) malā he bagh-un gammat vāt-at hoti me.Dat this see-Ger amusement feel-ing was

(mr.upakram.org/node/1875)

'Seeing this, I was feeling amused.' [Lit: 'Seeing this, amusement was seeming to me.']

Use of these tests as diagnostics of syntactic agenthood is common in the Indo-Aryan linguistics literature (see PANDHARIPANDE 1997: 212-216; DhONGDE \& WAli 2009: 187). 
(6)

[[ek moṭhi bahịn āṇi lahān bhāu as-lel-ā]

(inalienable Possessor) ${ }^{6}$

one big sister and little brother be-PstPart

hā $\quad$ mulga $\bar{a}] \ldots$

this boy

'[This boy [(who) has a big sister and little brother]] ...'

(gaurangprabhu.blogspot.com)

(7)

kadāčit [[tu pyāy-lel-i] dāru $]$ atišay kaḍak as-el (Patient) perhaps you.Erg drink-Pst-Part-Fsg liquor(Fsg) very strong be-3sgFut

'Maybe [the liquor [(that) you drank]] may have been too strong.'

(www.loksatta.com)

(8)

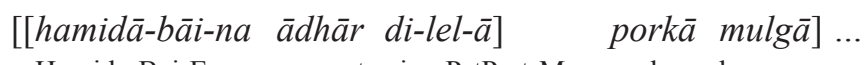

Hamida-Bai-Erg support give-PstPart-Msg orphan boy

'[The orphan boy [(that) Hamida Bai gave support (to)]] ...'

(globalmarathi.com)

In (9) through (12) the positions relativized on belong to the category of oblique objects:

[[bhājyya dhuṭ-lel-a] pāni $] \quad$ dthāọān-nā ghāl-ā

vegetables wash-PstPart-Nsg water(Nsg) trees-Dat pour-Imper

'Pour on the trees [the water $[$ (that) $[\mathrm{x}]$ washed veggies (with) $]]$...'

(navshakti.co.in)

(10)

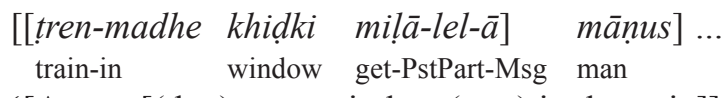

(Locative-goal)

'[A man [(that) got a window (seat) in the train]] ...'

(prajaktzaware.blogspot.com)

(11)

[[brahm.dev nighā-lel-i] nābhi] āhe

(Ablative Source)

Brahma come.out-PstPart-Fsg navel(Fsg) is

'There is [the navel [(that) Brahma emerged (from)]].'

(vitthalrukminimandir.org)

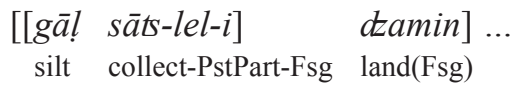

(Location)

'[Land [(that) sediment collected (on)]] ...' (72.78.249.126/Agrowon)

6 In Marathi the inalienable Possessor is assigned the dative case as in (a):

(a) tyā-lā hāt, pāy, doka āhe

him-Dat hand foot head is

'He has hands, feet, and a head.' (72.78.249.125)

Like the Experiencer, the inalienable Possessor controls the gerund:

(b) mothāa ho-un malā jevhā mula ho-til...

big become-Ger me.Dat when children be-Fut3pl

'When I'll grow up and have kids ...' (bandyagundi.blogspot.com)

See Pandharipande 1997: 231; Dhongde \& Wali 2009: 291, and Subbarao 2012: 272.

7 It is a toss-up whether the full-clause counterpart has pānya $\bar{a}-t$ 'in the water' or $p \bar{a} n y \bar{a}-n e$ 'with the water'.

The choice may depend on the size of the item washed. 
Marathi distinguishes two kinds of possessor: Alienable and inalienable. Both kinds can be relativized on with a PPP:

$$
\begin{aligned}
& {\left[\begin{array}{lll}
k a \bar{r} r d & n \text {-as-lel-e }] \quad l o k
\end{array}\right] . . \quad \text { (alienable Possessor) }} \\
& \text { card not-be-PstPart-Mpl people(Mpl) } \\
& \text { '[People [(who) do not have (ration) cards]] ...' (divyamarathi.bhaskar.com) }
\end{aligned}
$$

Relativization on object of comparison (the last position on the NPAH) is outside the scope of the PPP and must be rendered with a relative-corelative construction:

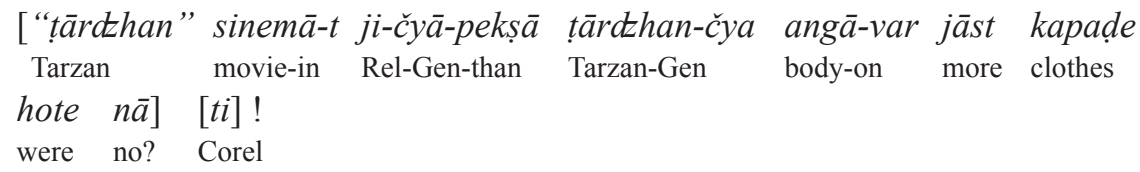

'[That one] [who Tarzan had more clothes on than, right?]'

(atakmatak.blogspot.com)

The non-past participle in -nār - appears in PPPs relativizing on all the positions in Keenan and Comrie's NPAH except those of Direct Object and Indirect Object:

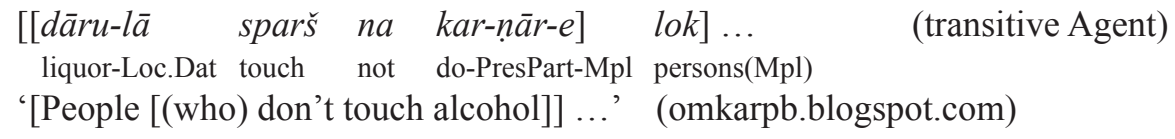

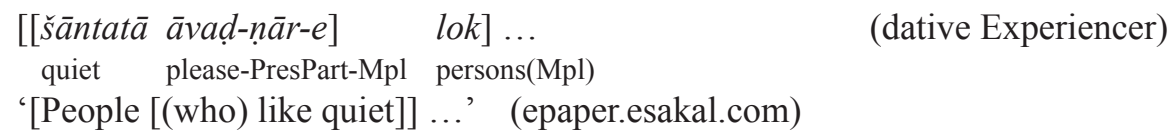

(www.loksatta.com)

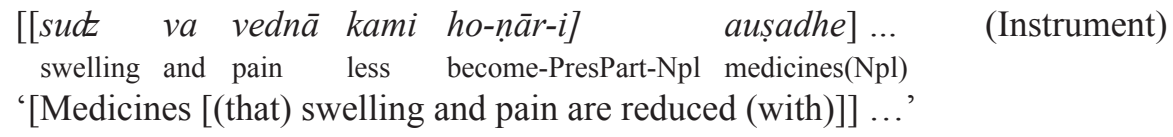

(www.saptahiksakal.com)

[[jāst $\quad \bar{a} v \bar{a} d z \quad$ ho-ṇār-i] $\quad$ upakaraṇe $]. .$.

excessive noise become-PresPart-Npl devices( $\mathrm{Npl})$

'[Devices $[$ (that) too much noise is produced (by )] ...' $\quad(72.78 .249 .107)$

$\begin{array}{lllll}{[[\text { bhar.pur }} & \text { pagār } & \text { mill-nār }-\bar{a}] & \text { mānus }] \ldots & \text { (Locative-goal) } \\ \text { full } & \text { salary } & \text { get-PstPart-Msg } & \text { man } & \end{array}$

'[A man [(that) gets a generous salary]] ...' (www.misalpav.com/node/12439)

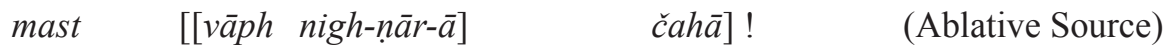

$$
\begin{aligned}
& \text { delightful steam come.out-PresPart-Msg tea(Msg) } \\
& \text { '... a perfect (cup of) [[(that) steam comes out (from)] tea]!' }
\end{aligned}
$$




$$
\begin{aligned}
& \left.\left[\begin{array}{lll}
{[p \bar{a} n \underline{i}} & s \bar{a} t s-n ̣ \bar{a} r-i]
\end{array}\right] \quad \text { dzamin }\right] \ldots \quad \text { (Location) } \\
& \text { water collect-PresPart-Fsg land(Fsg) } \\
& \text { '[Land [(that) water collects (on)]] ...' (www.agrowon.com) } \\
& \text { [[paise n-as-ñār-e ] lok] garib as-tāt (alienable Possessor) } \\
& \text { money not-be-PstPart-Mpl people(Mpl) poor be-Pres3pl } \\
& \text { '[People [(who) do not have money]] are poor.' (www.loksatta.com/daily) }
\end{aligned}
$$

\section{VIOLATIONS OF THE NPAH}

Examining the first of these two datasets [(4)-(13)] we see that PPPs in -lel- do not violate the constraints proposed by Keenan and Comrie. However, Marathi's PPPs in -nār [(15)-(23)] do violate those constraints. They allow relativization on subject and Agentpositions on the extreme left of the NPAH - and positions (oblique objects [(18)-(22)] and alienable Possessor) on the far right. The gap in the middle, the inability of PPPs in -nār-to relativize the positions of direct object and [with Modern Greek (JOSEPH 1983)] indirect object makes Marathi an exception to the universal that Keenan and Comrie proposed.

Patients and Recipients may be relativized by $-n \bar{a} r$ - provided that they are in PPPs in which they figure not as nulled or gapped direct and indirect objects but as subjects:

$$
\begin{aligned}
& \text { [[āi-kadun mār } \quad k h \bar{a}-n ̣ \bar{a} r-i] \quad m a \bar{j} h i \quad b a h i n ̣] \ldots \quad \text { (nulled subject=Patient) } \\
& \text { '[My sister [(who) would be beaten by (our) Mom }]] \text {...' }
\end{aligned}
$$

(harinarke.blogspot.com)

$$
\begin{aligned}
& \text { [[sarkār-či madat ghe-ṇār-e }] \quad \text { madtur }] \ldots \text { (nulled subject }=\text { Recipient }) \\
& \text { government-Gen help take-PresPart-Npl laborers } \\
& \text { '[Laborers [(who) receive government assistance]] ...' (ketkardnyankosh.com) }
\end{aligned}
$$

The general inability of - $n \bar{a} r$ - PPPs to relativize on direct and indirect object positions may have more to do with -nārr-'s morphological history than with syntax or semantics. Jules BLOCH (1970: §258) discusses but then hesitates to accept the theory that -nār- is derived from the infinitive in - $n$ - plus a remnant of the agentive suffix -dhäraka 'supporter'. ${ }^{8}$

In addition to 'Experiencer subject' (5) and (16) Marathi requires a few other positions that are not on the NPAH in order to accommodate subcategorized relations of nulled head noun to the PPPs predicate. One of them - which we may term the 'predicative' or 'essive' - is the relation between a subject and its nominal or adjectival predicate:

$$
\begin{gathered}
{\left[\begin{array}{clll}
{[e k e-k \bar{a} l-i} & \text { sakkhe mitr as-nār-e }] \quad \text { te }] \text { pakke šatru dthāle } \\
\text { one-time-Loc truest friends be-PresPart-Mpl they firmest enemies became }
\end{array}\right.} \\
\text { '[They [(who) once were best of friends]] became worst of enemies.' }
\end{gathered}
$$

(marathi.yahoo)

8 Against Bloch's hesitation we might adduce data from other Indo-Aryan languages:

(a) de-n.dār hamāre nikaț nahĩ phațak-egā aur le-n.dā hamārī čaukat nahĩ čhor-egā give-r our near not approach-Fut and take-r our door(frame) not leave-Fut 'The debtor won't come near me; the creditor won't leave my door.' (panchjanya.com)

Perhaps the $[d]$ of Hindi-Urdu le.n.dār 'creditor' is one reflex of OIA [-dh-] while the $[h]$ of de.ne.hār-in dūdh de.ne.hār.ī bakri 'milk-giving goat' is another. Both point to -dhāraka. 


$$
\begin{aligned}
& \text { [[šet.kary.ān-tse mitr as-lel-e }] \quad \text { vividh jāti-tse sāp] ... } \\
& \text { farmers-Gen friends be-PstPart-Mpl various kind-GenMpl snakes } \\
& \text { '[Snakes of various kinds [(who) are the farmers' friends]] ...' }
\end{aligned}
$$

(article.wn.com)

Another relation that is absent from the NPAH is the genitive of Patient: ${ }^{9}$

$$
\begin{array}{cc}
{\left[\left[\begin{array}{l}
\text { tsori } \\
\text { theft }
\end{array}\right.\right. \text { become-PresPart-Mpl }} & \begin{array}{l}
\text { paise }] \ldots \\
\text { money(Mpl) }
\end{array} \\
\text { '[Money }[\text { (that) is stolen }]] \ldots & \text { (maharashtratimes.indiatimes.com) }
\end{array}
$$

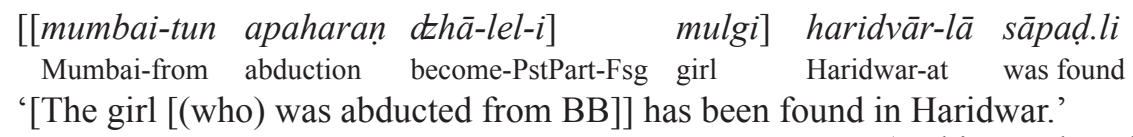

(archive.prahaar.in)

\section{TWO CLASSES OF POSITIONS ON THE NPAH}

In more than half of the data presented so far, the relationships of the PPP's nulled elements to their predicate [that is, to the verb or complex verb in participial form] are ones subcategorized [that is, lexically required or projected] by that predicate: intransitive subject, Agent, Patient, dative Experiencer, inalienable Possessor, Recipient, ablative Source, and Locative-goal. These are the eight grammatical relationships that are lexically required by sets or subsets of Marathi predicates. ${ }^{10}$ Almost all Marathi intransitive predicates require a subject; ${ }^{11}$ transitive predicates, an Agent and a Patient; ditransitives, an Agent, a Patient

9 The full-clause counterpart of (29) has a genitive of the person abducted:
(a) tin varșān-čya muli-tsa apaharaṇ dthāala
three years-Gen girl-Gen abduction became-PstNsg
'The abduction of a three-year old girl occurred.' (www.ibnlokmat.tv)

In the full-clause counterpart of (28) the Patient is the subject of a complex predicate:

$\begin{array}{lll}\text { (b) } & \text { tsori } & \text { dtha }-l-e \\ \text { money(Mpl) theft(Fsg) } & \text { became-Pst-Mpl } \\ \text { 'The money was stolen.' } & \text { (www.loksatta.com) }\end{array}$

We take the incorporation of the noun tsori in (b) as alternating with its non-incorporation:

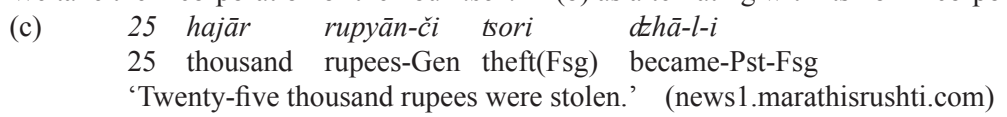

10 Instrument seems to be an exception: The instrumental relation of aușadhe 'medicines' to kami hoṇe 'to become less' in (18) is not subcategorized by that predicate. The relation of (18) to a synonymous alternant in kami karne 'to reduce' is discussed in Hook and Pardeshi (MS).

11 Exceptions to the subject requirement include verbs like ujādne 'to dawn', andhārne 'to get dark' when used impersonally. Note the default neuter singular verb form in (a):
(a)
$\bar{a} t \bar{a} \quad$ tsāngla-ts ujāḍ-la
now well-Emph dawn-PstNsgDef
'Now the dawn was well advanced.'
hot-a
was-NsgDef
(envis.maharashtra.gov.in)

However, some of the same verbs can be used personally, too:

(b) Ševați ravi.vār-tsā divas $\quad$ ujād-lā
finally Sunday-Gen day(Msg) dawn-PstMsg
'Finally Sunday dawned.' (kayvatelte.com)

Dhongde and Wali provide a sampling of MARATHI's impersonal sentences (2009: 200-201). 
and a Recipient; most experientials, a dative Experiencer; verbs asserting [not presupposing] inalienable possession, a Possessor, ${ }^{12}$ verbs of emergence, an ablative Source; and those of residence or placement, a Location or Locative-goal. These relations belong to Class One.

Relationships in which the PPP's nulled element corresponds to a genitive that is part of a complex noun phrase (30) or to an adjunct of time (31a) or place (31b) that is not subcategorized by the predicate with which it occurs belong to Class Two:

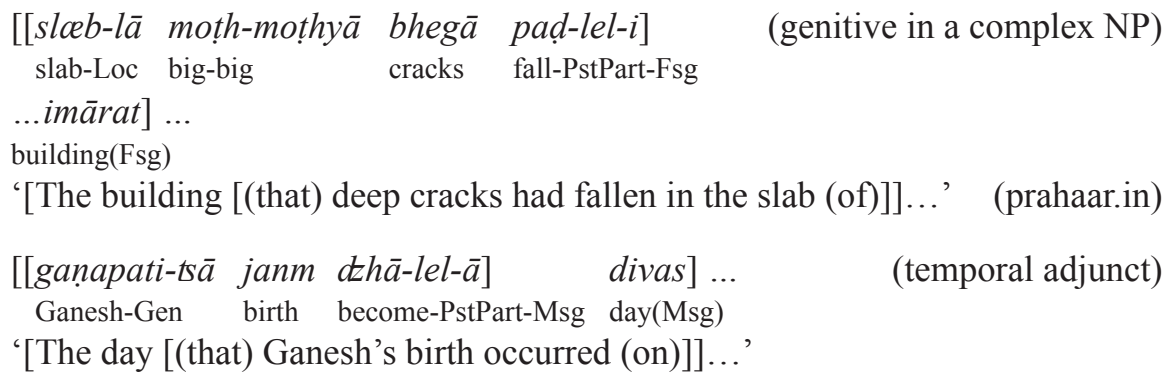

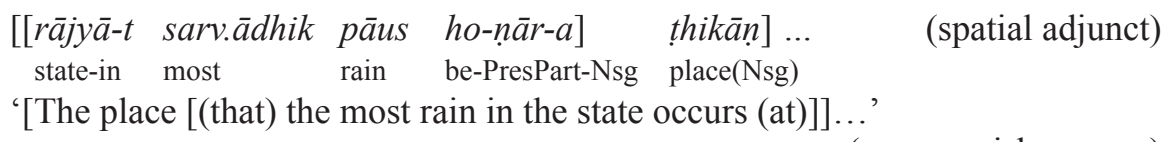

(cms.myvishwa.com)

In this section we contrast prenominal PPPs that relativize on positions on the NPAH that are subcategorized by the predicates they contain with those PPPs in which the nulled element is an adjunct or one having a weak or indirect thematic relation with the predicate of its PPP. Or no relation at all. ${ }^{13}$ Compare (32) to (12) [repeated below]:

$$
\begin{aligned}
& \left.\bar{a} p l y \bar{a}-l \bar{a}-t s \quad\left[\begin{array}{lll}
m \bar{a} s ̌ i & m e-l e l-\bar{a}
\end{array}\right] \quad \text { pāv }\right] \quad \text { mill-ṇe ... } \\
& \text { we-Dat-Emph fly die-PstPart-Msg bread(Msg) get-Inf } \\
& \text { '...for us to get [the bread [(that) a fly died (in it)]]...' (www.misalpav.com) }
\end{aligned}
$$

The difference between (32) and (12) is that the locative-goal of the sediment in (12) is a necessary complement of the verb säts- 'collect':

$$
\begin{array}{llll}
g \bar{a} l & \text { sāts-lel-i } & \text { dzamin ... } & \text { (object of locative postposition) } \\
\text { silt } & \text { collect-PstPart-Fsg } & \text { land(Fsg) } & \\
\text { '[Land [(that) sediment collected (on) }]] \ldots ' & \text { (72.78.249.126/Agrowon) }
\end{array}
$$

In contrast to (12), the location of a death is not a required complement of the verb mar- 'die'. That is, the location of a death is not subcategorized by the verb mar.ne 'to

12 The co-occurrence of inalienable possessor nouns with the verb asne 'to be' [(6) and (17)] has to be thought of as inhering in the construction as a whole.

${ }^{13}$ In his recent monograph on South Asian languages SubBarao has invoked absence of a thematic relation between the nulled element and its predicate as an explanation as to why comitative PPPs are not permitted unless either the comitative postposition is retained in the PPP or a reciprocal form of the verb or an adverb meaning 'together' is present in it (2012: 304-308). A counter-example from the Gultari dialect of eastern Shina, an IndoAryan language of the Northern Areas of Pakistan (Hook 1997: 143):

(a) [lżo-i bēy $]-e k$ jery $]-e \quad$ gin-i waž-oni raž-e he-Emph sits-one old.Fsg-Acc take-Ger come-Inf say-M3plPst 'They told him to bring [the old (woman) [(that) he sits (with)]].' (roni gā pharāaro, 1. 48) 
die'. The noun $p \bar{a} v$ 'bread' in (32) is the unsubcategorized location of the subject of an intransitive. Among the consequences of this difference is that people [farmers, at least] may regard gầl sātsleli dzamin 'silted land' as an established category or a kind of land whereas māši melela $p \bar{a} v$ 'bread with a dead fly in it' is hard to think of as being an established kind of bread.

Let us consider another contrasting pair:

$$
\begin{aligned}
& \text { [[äi-vadil n-as-lel-i }] \quad \text { an.ek mula }] \ldots \\
& \text { mother-father not-be-PstPart-Npl many children(Npl) } \\
& \text { '[Many children [(whose) parents are not]]...' (abpmajha.newsbullet.in) }
\end{aligned}
$$

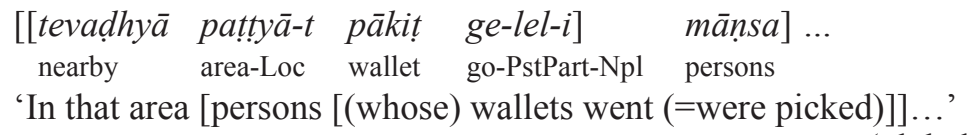

(globalmarathi.com)

In both (33) and (34) the relation of the head noun to the PPP is that of possessor. But in (33) mention of the possessor is required to complete the sense of the predicate $\bar{a} i$-vadil nasne 'to lack parents' whereas in (34) mention of the (ex-)possessor of the stolen wallet is not required in order to understand the meaning of päkit gela 'a wallet was stolen'. The relation of the meaning of pākit gela to mānsa 'persons' is more indirect or peripheral than the relation of a $i$-vadil nāhit to mula 'children'.

Consequently since the relation is much looser the contents of a PPP modifying a peripheral possessor of the sort we see in (34) can vary much more than can the contents of a PPP modifying a subcategorized possessor of the sort we see in (33). For instance, the possessor of a locative-goal may be modified by an indirectly related PPP:

$$
\begin{aligned}
& \text {... [[ gharāa-t pāṇi šir-lel-yā }]] \quad \text { lokān-nā ... } \\
& \text { house-LocDat water enter-PstPart-Obl people-Acc } \\
& \text { '... [persons [(into whose) houses [water entered]]] ...' (www.tarunbharat.net) }
\end{aligned}
$$

The head in (36) is the possessor of the Patient-subject of a derived intransitive [tsori ho-]:

$$
\begin{aligned}
& \text { [[dāgine tsori dthā-lel-yā }] \quad \text { mahile-ne }] \text { dilelyā oḷhi-nusār ... } \\
& \text { jewelry theft become-PstPart-Obl woman-Erg given identification-according ... } \\
& \text { 'In accord with the ID given by [the woman [(whose) jewelry was stolen]] ...' }
\end{aligned}
$$

In all three of (34-36) the full-clause counterpart of the PPP uses the genitive case in a complex noun phrase to indicate the relation of the possessor to the wallet, to the houses, to the jewelry. Again, in (37) the constituent lokān-čyā gharāt 'into people's houses' is a complex NP. In (37) [lok], the possessor of the houses, has no grammatical relation to the verb in the full-clause predicate pāṇi širla 'water entered'. Nor does it in (35).

$$
\begin{aligned}
& \text { dzor.dār pāus dzhālā, lokān-čyā gharāt pāṇi šir-l-a [compare (35)] } \\
& \text { strong rain occurred people-Gen house-LocDat water enter-Pst-Nsg } \\
& \text { 'There was heavy rain. Water came into people's houses.' }
\end{aligned}
$$


In contrast with (37), the full-clause counterpart of the PPP in (33) has the possessor not in an NP but in the dative case, in direct grammatical relation to the predicate of the clause:

$$
\begin{aligned}
& \text { bahu.saykhy rāb-ṇār-yā alp-vayin mulān-nā āi-vaḍil nāhi-t } \\
& \text { majority labor-ing-Obl under-age children-Dat mother-father not-3pl } \\
& \text { 'Most of the under-aged kids who are working do not have parents.' }
\end{aligned}
$$

(divyamarathi.bhaskar.com)

This can be put in another way: In (33) the head noun mula is directly modified by the contents of its PPP while in (35) the head noun loka is indirectly modified by the contents of a PPP which it 'hosts'. Based on this difference we make the following generalization:

The looser the relation of the head to the contents of its PPP, the greater the variety in the types of PPPs that it may host.

\section{THE MISSING AGENT MYSTERY [AS YET UNSOLVED]}

The striking reluctance of speakers to include an overt Agent or Experiencer seen in PPPs [(40), (41), (42), (43), (44)] remains to be verified and explained.

Location [gharāt] of a transitive action [sori kar-] with absent Agent:

$$
\begin{aligned}
& {[[\text { tsori ke-lel-yā }] \quad \text { gharā }-t] \ldots} \\
& \text { theft do-PstPart-Obl house-in }
\end{aligned}
$$

(maharashtratimes.indiatimes.com)

Location [raste] of an experience [thaṇdi vādtne] with absent Experiencer:

$$
\begin{aligned}
& \text { [[thandi vādt-ṇār-e }] \quad \text { raste }] . . . \\
& \text { cold feel-PresPart-Mpl roads(Mpl) } \\
& \text { '... [roads }[\text { (that) }(e) \text { feels cold (on) }]] \ldots ' \text { (www.loksatta.com) }
\end{aligned}
$$

Cause of an experience (with an absent Experiencer):

$$
\begin{aligned}
& \text { [[thaṇdi vāctz-nār-e] botsre vāre }] \ldots \\
& \text { cold feel-PresPart-Mpl biting winds(Mpl) } \\
& \text { '[Biting winds [(that) }(e) \text { feels cold (because of)]] ...' (tarunbharat.net) }
\end{aligned}
$$

Possessor [divas] of the Patient [vičār] of an Agentless transitive [karṇe] 'do':

$$
\begin{aligned}
& \text { [[kadhi-hi vičār na ke-lel-ā }] \text { divas] ujād-lā } \\
& \text { ever-also idea not do-PstPart-Msg day(Msg) dawn-PstMsg } \\
& \text { '[A day [(that) (e) never even imagined]] dawned.' (www.haushilekhak.com) }
\end{aligned}
$$

Temporal location [divas] of the Agent-subject $[(e)]$ of a transitive [karne] 'do':

$$
\begin{aligned}
& {[[j a n-m a t \quad t s a ̄ t s n y \bar{a} \text { ke-lel-ā }] \quad \text { divas }] \ldots} \\
& \text { public-opinion test do-PstPart-Msg day(Msg) } \\
& \text { '[The day }[(\text { that })(e) \text { conducted a poll] }] . . . \text { (www.saamana.com) }
\end{aligned}
$$


However, it seems from (45) that the absence of Agents in PPPs may be a tendency rather than absolute:

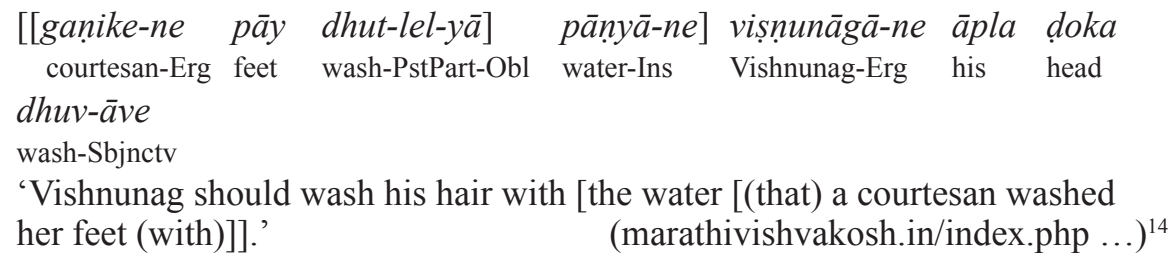

\section{PPPS AND PICTURE NOUNS}

We close with some data for which analysis in terms of the head of a PPP hosting an immediately related modifying participial phrase can't be made. ${ }^{15}$ In (46) and (47) we have examples of the transfer of the PPP modifying the 'subject' or the intended imagee of an image to the image itself:

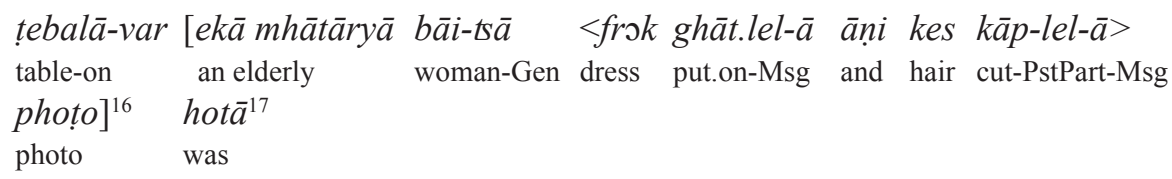

'On the table was a photo of an elderly woman in (Western) dress \& with bobbed hair.'

(www.lokasatta.com)

$$
\begin{aligned}
& \text { [ donhi mulān-tsāa <dāt dākhav-ṇār-ā> phoṭo] kāạh-to àtā } \\
& \text { both children-Gen teeth show-PresPart-Msg photo draw-Pres1sg now } \\
& \text { 'Now I will take a photo of both of the kids showing their teeth (= smiling).' } \\
& \text { (sahajachwordpress.com) }
\end{aligned}
$$

In (46) and (47) the PPP applies semantically to a nulled entity which in turn is imaged by photo, the noun phrase which hosts the PPP. We may think of photo as a 'see-through' noun. Although its modifiers form a morphosyntactic constituent with the noun photo they are to be understood as applying not to it but to the imagee depicted in it.

${ }^{14}$ However, example (45) is from a narration of the plot of a bhạn so the presence of an Agent in the PPP may reflect patterns of Sanskrit syntax in which explicit mention of the PPP's Agent is the norm.

${ }^{15}$ In his pioneering study of PPPs in Japanese, Teramura cites examples "in which the underlying sentence from which the modifying phrase is derived do not contain the same noun as the modified noun" as instances of an "outer relationship" (1969: 66). The first four sections of our paper treat a type of construction "in which the modifying element is derivable from a sentence which contains the same noun as the noun which is modified." This he calls an "inner relationship."

${ }^{16}$ Angled brackets ("<" and ">") indicate a semantically mismatched ('reindexed') constituent.

${ }^{17}$ Modification of 'see-through' nouns like phoțo displays oddities in other languages, too:

... [the <clean shaven $>$ photograph of Lincoln] made before he became president ... (google)

Hindi-Urdu (whose PPPs have more limited range) also allows transferred modification:
(a)
apn
$<$ pošăk pahan-e.hue>
foto]
hamẽ bhej-ẽ
self's costume wear-PstPartMpl photo(Mpl) us.Dat send-Imper

'Send us photographs (that) you've worn your costume in.' (beautiful-chandigarh.blogspot) 
A noun referring to an image may attract a PPP from the imagee to itself:

[gan.pati-či <bas-lel-i pakhvāct vadt.av-nār-i> murti] āhe
Ganesh-Gen sit-PstPart-Fsg drum play-PresPart-Fsg image is
'There is a seated drumming image of Ganesha ...'

(www.maayboli.com/node/622)

Even the word $\bar{a} v \bar{a} d z$ 'sound' when it creates a sonic image of a source may attract a PPP:

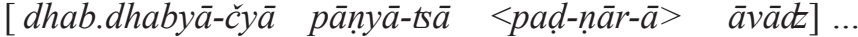

$$
\begin{aligned}
& \text { waterfall-Gen water-Gen fall-PresPart-Msg sound } \\
& \text { '... the sound of the waterfall's water falling ...' (mr.wikipedia.org/wiki) }
\end{aligned}
$$

In (49) even though (grammatically) the participle paḍnāra 'falling' modifies $\bar{a} v \bar{a} c t$ 'sound', it is not sound that is falling but the waterfall's water.

Such transfers or mismatches are optional. Compare (50) with (48) and (51) with (49):

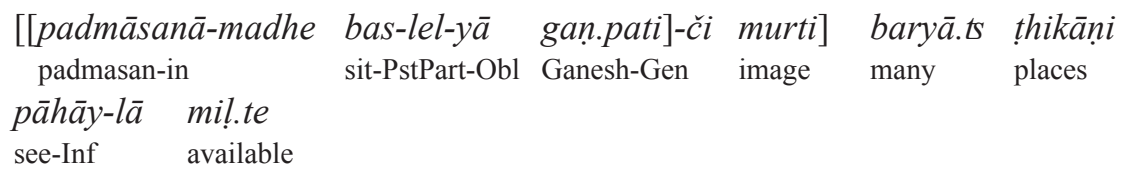

'Many places you can see an image of Ganesha sitting in the lotus position.'

\begin{tabular}{|c|c|c|c|c|}
\hline $\begin{array}{l}\text { [[dhab.dhaby } \bar{a}-t s \bar{a} \\
\text { waterfall-Gen }\end{array}$ & $\begin{array}{l}\text { kivãa } \\
\text { or }\end{array}$ & $\begin{array}{l}\text { dtorōa-t } \\
\text { force-in }\end{array}$ & $\begin{array}{l}\text { paḍ-ṇār-yā } \\
\text { fall-PresPart-Obl }\end{array}$ & $\begin{array}{l}p \bar{a} n ̣ y \bar{a}]-t s \bar{a} \\
\text { water-Gen }\end{array}$ \\
\hline
\end{tabular}

(mr.wikipedia.org/wiki)

(1000chandra.blogspot.com)

Ongoing research suggests that the degree to which picture nouns can attract a PPP away from the imagee [that is, its semantic modifiee] depends on the referential properties of the imagee. ${ }^{18}$ Personal pronouns (52) and (53) as well as proper nouns (54) almost always relinquish their PPPs:

$$
\begin{array}{clllll}
{[\bar{a} p l \bar{a}} & <\text { lāmb } & \text { kes } & \text { as-lel-ā }> & \text { photo }] & \text { ti-ne aplod ke-lā } \\
\text { self's long } & \text { hair be-PstPart-Msg photo she-Erg upload do-Pst }
\end{array}
$$

'She uploaded a photo of her(self) having long hair.'

(divyamarathi.bhaskar.com)

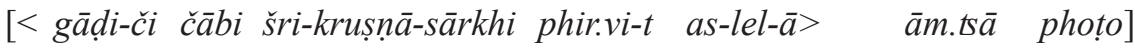

$$
\begin{aligned}
& \text { car-Gen key Shri-Krishna-like spin-ing be-PstPart-Msg our (=my) photo } \\
& \text { '... a photo of me twirling the car keys like Lord Krishna ...' }
\end{aligned}
$$

(sachinkhallal.blogspot)

${ }^{18}$ At first glance the variation in the power of different referential classes of imagees to prevent or to promote the transfer of PPPs seems to parallel Michael SiLvERSTEIN's Animacy Hierarchy (1976):

(a) pronouns $>$ proper names $>$ humans $>$ non-human animates

However, while referential classes of imagees toward the left of this scale are more likely to cede their PPPs to picture nouns than are those on the right, what little data we have found on inanimate imagees suggests that that segment does not conform to the animacy hierarchy. 


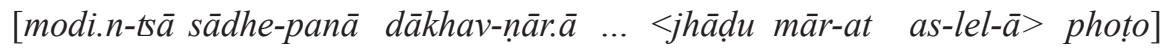
Modi-Gen simple-ness show-PresPart ... broom wield-ing be-PstPart photo '... a photo of Modi wielding a broom, showing (his) simplicity, ...'

(aarsaa.blogspot)

From data collected so far it seems that nouns referring to animals do not cede their PPPs:

[[sāṇd-lele pāni pi-ṇār-yā mākaḍa-tsāa phoṭo] spill-PstPart water drink-PresPart-Obl monkey-Gen photo

'... a photo of a monkey drinking spilt water ...'

(www.maayboli.com/node/18823)

$$
\begin{aligned}
& \text { [ [maje-t lol-at paḍ-lel-yā bibatyā-tsā }] \text { phoṭo }] \ldots \\
& \text { pleasure-in roll-ing fall-PstPart-Obl leopard-Gen photo } \\
& \text { '... a photo of a leopard blissfully rolling about ...' (www.maayboli.com) }
\end{aligned}
$$

Common nouns denoting humans and nouns naming gods sometimes cede their PPPs [see (46), (47) and (48)], and sometimes do not [(50) and (57)]:

$$
\begin{aligned}
& \text { [[mumbai-t-il sṭediyam-var khel-ṇār-yā] mulān-či }] \text { čhāyā.čitr }] \\
& \text { Mumbai-in-Adj stadium-Loc play-PresPart-Obl children-Gen photos } \\
& \text { '... photos of children playing at Bombay Stadium ...' }
\end{aligned}
$$

(www.globalmarathi.org)

Consequently, with images of humans the degree of specificity of the imagee plays a role. In (58) the imagee is generic and the PPP remains in place while in (59) the imagee is identified as the photographer's own child and the PPP is transferred to photo:

$\left[\begin{array}{lllll}{[g h \bar{a} t \bar{a}-v a r} & u b h y \bar{a} & \text { as-lel-ya } & \text { māns } \bar{a}-t s \bar{a}] \text { photo }] \text { phārats khās! } \\ \text { ghat-on standing be-PstPart-Obl man-Gen photo very.Emph special }\end{array}\right.$
'The photo of the man standing on the ghat is really great!'

(www.misalpav.com)

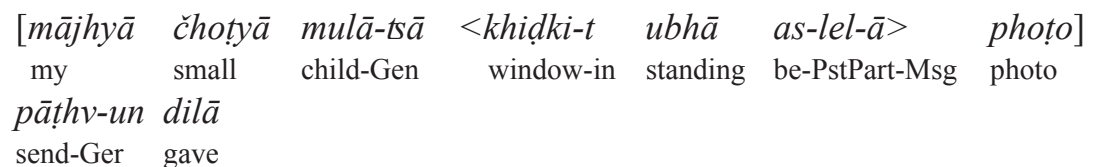

'I sent off a photo of my little boy standing in the window.'

(majhekavadase.blogspot)

In the data displayed in examples (46) through (59) we see neither chaos nor a serious contradiction to the NPAH. Rather, these data show how semantics may mismatch syntax in a regular and predictable way. That is ultimately in the spirit [if not the letter] of Keenan and Comrie's seminal, now nearly forty year old, contribution to the study of universals in typological linguistics.

\section{ABBREVIATIONS}

1 - first person; 2 - second person; 3 - third person; Acc - accusative; Cor(el) - co-relative; Dat - dative; Def default; Emph - emphatic particle; Erg - ergative; F - feminine; Fut - future; Gen - genitive; Ger - gerund; Imper - imperative; Ins - instrumental; Loc - locative; $\mathrm{M}$ - masculine; $\mathrm{N}$ - neuter; Nom - nominative; Obl - oblique; Part - participial; pl - plural; Pres - present; Pst - past; Rel - relative; Sbjnctv - subjunctive; $\operatorname{Tr}$ - transitivizer 


\section{REFERENCES}

Annamalai E. 1997. Adjectival Clauses in Tamil. ILCAA, Tokyo Univ of Foreign Studies.

BLoch Jules. 1914/1920/1970. La formation de la langue marathe [The formation of the Marathi language]. D.R. Chanana (transl.). Delhi: Motilal Banarsidass.

Comrie Bernard, Keenan Edward L. 1979. "Noun Phrase Accessibility Revisited.” Language 55, 649-664.

Dixon Robert M.W. (ed.). 1976. Grammatical Categories in Australian Languages. Canberra: Australian Institute of Aboriginal Studies.

DHONGDe Ramesh, Wali Kashi. 2009. Marathi. Amsterdam: John Benjamins.

Hоок Peter E. 1997. "Relative Clauses in Eastern Shina.” In: Michalove et al. 1997: 140-154.

Hook Peter E., Koul Omkar. MS. The Noun Phrase Accessibility Hierarchy and Participial Noun-modifying Constructions in Hindi-Urdu and Kashmiri.

Hook Peter E., PARDESHI Prashant. In press. "Noun-modifying Constructions in Marathi." In a volume on PPPs in Asian languages edited by Y. Matsumoto, B. Comrie, and P. Sells.

JosePH Brian. 1983. "Relativization in Modern Greek: Another Look at the Accessibility Hierarchy Constraints." Lingua 60, 1-24.

KeEnan Edward L., Comrie Bernard. 1977. "Noun Phrase Accessibility and Universal Grammar." Linguistic Inquiry 8(1), 63-99.

Masica Colin P. 1991. The Indo-Aryan Languages. Cambridge University Press.

Michalove Peter, Hegedüs Irèn, Manaster-Ramer Alexis (eds). 1997. Indo-European, Nostratic and Beyond: Festschrift for Vitalij V. Shevoroshkin. Washington: Institute for the Study of Man.

PANDHARIPANDE Rajeshwari. 1997. Marathi. London-New York: Routledge.

SiLVERSTeIN Michael. 1976. "Hierarchy of Features and Ergativity.” In: DiXon 1976: 112-171.

SRIDHAR S.N. 1990. Kannada. London: Routledge.

Subbarao K.V. 2012. South Asian Languages: A Syntactic Typology. Cambridge University Press.

Teramura Hideo. 1969. "The Syntax of Noun Modification in Japanese." The Journal Newsletter of the Association of Teachers of Japanese 6, 64-74. 